\title{
Upper Precambrian (Riphean) in the Southern Urals of U.S.S.R.
}

SIR - I offer to your readers an account of the Bashkirian (Southern Urals) excursion of the International Symposium 'Correlation of the Precambrian' held in August and September 1975 under the auspices of the International Geological Correlation Programme of I.U.G.S. and U.N.E.S.C.O. (A fuller report is appearing in Izvestia Akad. Nauk.)

The International Symposium 'Correlation of the Precambrian' was held in the Soviet Union from 21 August to 9 September 1975. It was organized by the USSR Academy of Sciences and by the Ministry of Geology of the USSR and was carried out within the framework of the International Geological Correlation Programme (IGCP) and sponsored jointly by UNESCO and the International Union of Geological Sciences (IUGS). The Symposium session held in Moscow was preceded by two field excursions - to Bashkiria and to Karelia.

The Bashkirian excursion took place on 22-31 August, 1975 to demonstrate the Upper Precambrian (Riphean) succession of the main rock-units and of the stromatolite assemblages in the Bashkirian anticlinorium (western slope of the Southern Urals). This section had been used as a basis for establishing Riphean as a time-stratigraphic subdivision of a high rank (Shatsky, N. S. 1945. Tectonic essays of Volgo-Ural oil-bearing region and adjacent part of south Urals. Materials for Knowledge of Geological Formation of USSR, N.S. extract 2 (6)M., Izd-vo Mosk. Ob-va ispyt pryrody.) and is considered to be its stratotype.

The excursion was organized by the Bashkirian branch of the USSR Academy of Sciences and by the Geological Institute of the USSR Academy of Sciences. Twenty foreign geologists from Australia, Brazil, Canada, England, France, Poland, Portugal, U.S.A., Czechoslovakia and twelve Soviet geologists from various organizations of Ufa, Moscow, Leningrad and Novosibirsk, took part in the excursion. Among the participants of the excursion there were members of the working groups on the following IGCP projects: 'Precambrian of mobile zones', 'Precambrian of younger fold belts', 'Upper Precambrian correlation', 'Precambrian-Cambrian boundary', 'Precambrian of West Africa'. Foreign and Soviet participants assembled in Ufa on 22 August. The observations started with Palaeozoic overlying Riphean in major lithostratigraphic complexes of the Bashkirian anticlinorium between 24 and 30 August. The main attention was paid to Middle, Upper and Terminal Riphean (Yurmata, Karatau and Asha) groups. Each day after the field trips informal discussions on principal points of Precambrian stratigraphy and palaeontology took place at the field camps and at the tourist centre in Kaga.

\section{General problems}

During recent years, significant progress has been made towards understanding and resolving problems of the subdivision and correlation of Precambrian rock units, utilising radiometric, geologic and palaeobiological principles and techniques but many problems of Precambrian stratigraphic subdivision and correlation, especially on a global scale, remain. Therefore the comprehensive study of the most complete reference sections of Precambrian deposits is of fundamental importance. One such well-studied succession is that of the western Urals of the Soviet Union: the Riphean stratotype.

Discussion on the most general problems of the Precambrian stratigraphy brought us to the following principal conclusions:

(1) Solution of the problems of Precambrian subdivision and correlation should be based on detailed understanding of the Precambrian rock record and of the fossils it contains, and on comparative analysis of well studied and complete Precambrian successions.

(2) Biostratigraphic methods hold promise for effective subdivision and correlation of the Precambrian rock units, especially of Middle Riphean and younger age (less than $1400 \mathrm{Ma}$ ).

(3) Although the Uralian section has been mildly metamorphosed, it appears to be reasonably complete, adequately exposed and easily accessible. At least in its upper global portions it could be of potential use as a reference section for global stratigraphy.

Many Precambrian strata hitherto correlated solely on the basis of radiometric age determinations may in future be correlated biostratigraphically. Assemblages of algal stromatolites, known for several years to be useful in intrabasinal studies, have now been extended with apparent success to correlations of an interbasinal, and even intercontinental scale, for example, correlations of Riphean strata in Australia, North

Geol. Mag. 114, (4), 1977, pp. 305-307. Printed in Great Britain. 
America, Northwest Africa and in the USSR. Stromatolites appear to provide an effective framework for subdivision of the Riphean into four time-stratigraphic units. Similarly, newly available data seem to suggest that Precambrian microfossils may ultimately provide a firmer basis for biostratigraphy. Such Precambrian fossils, now known from Australia, North America, Africa, India, Europe and Northern Asia, appear to be of relatively common occurrence in both macrofaunal skeletalised facies and stromatolitic facies.

In comparison with the Phanerozoic biota, however, the organisms now known from Precambrian rocks are notable both for their lack of biologic diversity and for their apparently slow rates of evolutionary change. Special problems thus exist, problems that in principle could serve to limit the degree of temporal resolution potentially available for application to Precambrian biostratigraphy. Nevertheless, it seems evident that at present increasing emphasis is being placed on application to Precambrian stratigraphy of those methods and techniques that have proven fruitful for subdivision and correlation of Phanerozoic rocks. Although some participants in the field conference thought that Precambrian rocks should be placed by radiometric means into artificially defined divisions, the majority of participants indicated preference for subdivision based on the occurrence of distinctive events in biological and/or geologic evolution.

\section{Riphean in Southern urals}

The participants of the excursion observed the upper part of the Terminal Riphean (Vendian) outcrops along the Kuk-Karauk stream and in Krivaya Luka along the Belaya river as well as some well-exposed Upper and Terminal Riphean sections in the valley of the Zilim river. Here one was able to see not only the composition of the rock-units, but their relationship as well. At several levels Riphean carbonate rocks contain stromatolites and microphytolites, which form distinctive successive complexes, and the presence of layers and lenses of black cherts permit us to suggest microfossils in these rocks. The Katav, Inzer, Miniar, and Uks formations contain glauconite-bearing rocks, which were dated by radiometric methods. The numbers are in the range $965-570 \mathrm{Ma}$ (using $\mathrm{K}=0.557 \times 10^{-10} \mathrm{y}^{-1}$ ).

Middle Riphean formations were observed at the Shatek ridge (the Mashak formation) and along the left bank of the Avzyan river, where the stratotype section of the fivefold Avzyan formation is exposed (K-Ar age on glauconite $1260 \mathrm{Ma}$ ).

Near the Ismakaevo village several scattered Lower Riphean outcrops were examined.

As a whole, the studied sequence of the Middle, Upper and Terminal Riphean rock units is well exposed and suitable for correlations.

According to N. S. Shatsky, and to some other geologists, Riphean deposits of the Southern Urals correspond to the complete tectonic cycle, which comprise volcanic strata of the initial Lower Riphean stage of the geosynclinal development, flysch-like Upper Riphean deposits and terrigenous Asha deposits, which were referred to by many authors as in Terminal Riphean molasse. From this point of view the Riphean sequence may be considered as an erathem. Some scientists distinguish several tectonic cycles within it.

The results of the investigation carried out by Soviet geologists in the last 10-15 years has proved that several other rock assemblages can be outlined in the Riphean Urals. Among the clastic units associated with the molasse-type assemblages, derived from the east, there are distinctive assemblages of quartz sandstones and siltstones derived from uplifts within the East-European platform. This type of molasse-like assemblage was distinguished as the Phalakh Formation.

The Riphean in the USSR is considered to be a large time-stratigraphic subdivision which corresponds to Upper Proterozoic and has the time-range $1650 \pm 50$ to $570 \pm 20 \mathrm{Ma}$. The lower boundary of the Riphean is, so far, defined tectonically.

This boundary separates the volcanogenic molasse and final plutonic events of the Karelian (Svekofennian) orogeny on one hand from the platform cover on the Epikarelian cratons and late Precambrian miogeosynclinal succession on the other. In the Uralian stratotype this boundary still needs to be made more precise and to be confirmed. It may be possible to do so after reliable data on isotope ages have been obtained.

Although it is evident that the Riphean qualifies as a distinctive independent time-stratigraphic division, the position of its exact upper and lower boundaries are still under discussion.

There is one opinion that Riphean Uralian sections start with the Mashak Formation of the Yurmata division separated by an unconformity from the underlying Burzyan division, traditionally considered to be the Lower Riphean type. Some students emphasize the importance of the boundary at the base of the Karatau sequence; this boundary was said to coincide with global tectono-magmatic events aged about $1.1 \mathrm{Ga}$. These students, stressing the transition of the Karatau rocks eastward into eugeosyncline successions with some traces of initial magmatism, the presence of flysch-like and molasse-type deposits in the Karatau-Asha succession and the definite biostratigraphic characteristics of Precambrian strata younger than 
$1 \mathrm{GA}$, believe that the Uralian section might be recommended for stratotypes for Late Precambrian time divisions from 1000/1100 Ma.

The problem of the Riphean upper boundary is closely related to the problem of the position in the stratigraphic scale of the youngest Upper Precambrian subdivision known in geological literature as Terminal Riphean, Vendomian, Vendian or Yudomian. Though some participants of the conference consider this subdivision as post-Riphean, the majority were of the opinion that the Riphean upper boundary coincides with the initial Cambrian boundary.

The relationships of the Riphean with the fossiliferous Cambrian deposits are not known in the Urals. This lack is to some degree compensated for by the following:

(1) Rare occurrences of Ediacara fauna representatives in the Asha strata, which confirm the correlation with the Vendian Valdai group in the Russian platform.

(2) Occurrence of the Valdai rocks below the Baltic division (probably? Early Cambrian Tommotian Age of Siberia).

On the basis of lithological and biostratigraphic data the fourfold subdivision of the Riphean has been recommended. These subdivisions are usually referred to in the Soviet geological literature as Lower, Middle, Upper and Terminal Riphean, or Vendian. Four divisions are traced in all the reference sections of the Riphean in the USSR and are of great importance in interregional correlations. In view of this it is desirable that these subdivisions have names.

\section{Comparison with sections of other countries}

Riphean as a large chronostratigraphic subdivision with the time-range $1650 \pm 50$ to $570 \pm 20 \mathrm{Ma}$ is widely used throughout the USSR and recently started to be used outside (for example in Australia, India, Africa, North America). The present knowledge of Precambrian geology, isotope geochronology and palaeontology not only suggests the presence of Riphean time-equivalents outside North Eurasia, but permits distinguishing equivalents of its four divisions. The Early Riphean rocks outside Eurasia are known from radiometric data and preliminary stromatolite study in Canada, Northern Australia, Central Africa and some other territories and it seems to be developed in India. According to palaeontological and radiogeochronological data the Middle Riphean rocks are considered to be widely distributed in the western part of North America, on the Korean-Chinese platform, in India, in Northern and Southern Australia. Late Riphean rocks are reported in Western and Central Africa, in Korea, in Central and Southern Australia, in the Northern Atlantic Region and elsewhere. Terminal Riphean (Vendian) rocks are traced in Western Africa, in Australia, in the Northern Atlantic region and elsewhere on the basis of palaeontological (Ediacara fauna, stromatolites), and/or palaeoclimatic (presence of the tillites of Vendian age) and radiometric data.

Thus the four Riphean divisions can be used in all continents. This suggests that the Riphean and/or its divisions are candidates for global chronostratigraphic divisions.

At present the current tasks in Riphean stratigraphy are the study of the distribution of plant microfossils, contained in cherts and shales, making more precise the knowledge of the systematics and ecology of stromatolites and microphytolites, obtaining $\mathrm{Rb}-\mathrm{Sr}$ isochrons and $\mathrm{U}-\mathrm{Pb}$ datings for the boundaries of the principal subdivisions, developing palaeomagnetic and palaeogeographical studies of the sections, especially those containing tilloids and tillites.

Acknowledgements. Thanks are expressed to all the organizers and especially to Professor B. M. Keller, Dr S. G. Fatakhutdinov, Professor M. A. Kamaletdinov, Drs. Yu. R. Bekker, V. I. Kozlov and other excursion guides; to the following Institutional organizers: the Ministry of Geology of the USSR, Academy of Sciences of the USSR, Soviet Committee for IGCP, Geological Institute of the Academy of Sciences of the USSR (Moscow), Bashkirian branch of the Academy of Sciences of the USSR and to its Geological Institute (Ufa) and the Board of the International Geological Correlation Programme (IGCP), which carries out its activities in close co-operation with International Union of Geological Sciences (IUGS) and UNESCO. Thanks also to the interpreters, drivers, helicopter crews, cooks and others.

G. Choubert, France; J. W. Cowie, United Kingdom; K. Jaworovski, Poland; B. M. Keller, U.S.S.R.; W. Schopf, U.S.A.; M. A. Semikhatov, U.S.S.R.; R. Trompette, France; V. Zoubek, Czechoslovakia.

Department of Geology

J. W. COWIE

University of Bristol

England

1 st December 1976 